\title{
Dynamics of a Protected Housing Market: The Case of Switzerland
}

\author{
Karol Jan Borowiecki
}

TEP Working Paper No. 1010

October 2011

Trinity Economics Papers

Department of Economics

Trinity College Dublin 


\title{
Dynamics of a Protected Housing Market: The Case of Switzerland
}

\author{
Karol Jan Borowiecki
}

\begin{abstract}
This study posits that there may be a strong relationship between the high degree of protectionism of the Swiss housing market and its stability. The article provides an overview of the Swiss housing policies that, it is argued, are highly conservative in the context of an international comparison. The stability of the Swiss housing economy is empirically tested. Based on the time period from 1990 to 2009, in which two substantial crises occurred, house prices and construction activity are modeled. The emerging results, which are admittedly based on a very short time series, are nonetheless consistent with previous theoretical and empirical research. Furthermore, the findings indicate that the Swiss housing economy operates in accordance with fundamentals. Based on a tentative approach that measures the occurrence of the crisis with annual indicator variables, no effects of the crises on the Swiss housing market can be detected.
\end{abstract}

Keywords: Housing Demand, Housing Supply and Markets

JEL Classification: R21, R31

Contact: Trinity College Dublin, Department of Economics, Dublin 2, Ireland. E-Mail: borowiek@tcd.ie. The author is grateful to Clemens Struck for his assistance and technical advice during this project. Helpful suggestions have been also received from Kenneth Gibb and anonymous referees. 


\section{Introduction}

The recent global financial crisis was unforeseen, of unexpected global dimensions and, to some extent, caused by the collapse of the United States housing bubble. This was not, however, the first real estate crisis in the U.S. and neither was America the only country where a national property crisis coincided with the distress of the entire economy. Property crises are notoriously recurring and leveraging of economic downturns. The recent financial crisis led to distress in most developed economies and in turn causing a significant drop in the price of property. There are however exceptions. The Swiss housing economy is such an exception and remains mostly unaffected by the recent 'Great Recession'.

That level of robustness of the Swiss housing market is possibly a result of its very high protectionism when compared internationally. The market is not easily accessible for foreign investors and it provides several disincentives for domestic speculators. Due to rigid taxation of home owners and conservative mortgage lending schemes the market is dominated by tenants. The formation of the Swiss housing market was shaped by several factors most significant of which was a substantial real estate economy crisis in the early 90's which stimulated the introduction of several protective regulations and practices. One question which is of potential interest for today's policy-makers is how well is the Swiss housing sector protected from economic turbulence? This is the question which is being addressed in this study. Furthermore, a summary of the Swiss housing policies that might have contributed to the stability of the market is provided.

The relationship between the degree of protectionism and house price dynamics is not straightforward. Ideally, one would want to conduct an international comparison of the degree of protectionism of national housing markets and study its role in housing value stability. Such an assessment is not, however, possible due to the lack of appropriate indices. As an approximation for the level of regulatory protection the Property Rights Index, provided by Global Property Guide (2011), is used. The suggested index is a sub-component of the Index of Economic Freedom and it indicates the degree to which a country's laws protect private property rights, as well as the degree to which its government enforces those laws. The association between the Property Rights Index and changes in European house prices over 10 years using the latest data available (as recorded by Global Property Guide, 2011) is illustrated in Figure 1. The emerging picture implies a strongly negative relationship with a correlation coefficient equal to -0.73 . The more regulated a national housing economy is a lower increase in house prices can be expected. Switzerland has the second lowest house price growth over the last 10 years and its Property Rights Index takes the highest value (i.e. 90 out of 100).

This study also provides an estimation of a model of the Swiss housing price and 
construction activity in order to investigate their interdependence as well as to identify their main drivers. The econometric analysis allows for further investigation of whether the economy is in accordance with fundamentals. The analysis is based on annual observations from 1990 to 2009 . The time period under investigation is particularly interesting as it facilitates some new understanding of the performance of a protected and conservative market at a time of some turbulence in international property markets. We construct a vector autoregressive model and find that house prices are positively related with construction price, working age population as well as GDP and are negatively associated with interest rates. Construction activity is stimulated by the size of the working age population and GDP; it discloses, however, a negative relationship with construction price and interest rates. The results are in accordance with theoretical as well as recent empirical research. It can further be concluded that the Swiss house price is in accordance with fundamentals. Furthermore, the recent financial crisis has barely had any effect on the Swiss housing market. Nonetheless, the econometric results have to be interpreted with caution as it is difficult to obtain reliable estimates for a short time period, especially if variables are interdependent with their own lags and the lags of other variables. In addition the detection of stationarity of variables can often not be conducted with high accuracy.

The remainder of this article is organized as follows. In the next section, the Swiss housing market is presented and compared with other national housing markets. In the third section, related literature is discussed and in the fourth the data sources are disclosed and the methodological approach introduced. In the fifth section, the empirical findings are presented and in the last section, concluding remarks are provided.

\section{The Swiss Housing Economy in an International Context}

As can be seen in Figure 2, the Swiss housing economy has been in an upward trend since the release of the major Swiss house price index (SWX IAZI Private Real Estate Price Index). ${ }^{1}$ Furthermore, there some indication of a 25 -year-long housing price cycle can be detected. The greatest increases can be observed during the Swiss construction boom of the early eighties, which was further leveraged in 1987 by the introduction of the Swiss Interbank Clearing System that led to a substantial money supply extension. Nonetheless, the bubble burst when the speculative belief of the market was confronted with the unexpected economic downturn of the early nineties.

Those events have forced the Swiss policy makers to introduce urgent sanctions on real estate speculation. While the timing of those sanctions has been criticized by some, their

\footnotetext{
${ }^{1}$ For a discussion of earlier house price changes and overview of historical developments in Swiss housing policy since World War II refer to Lawrance (1996).
} 
long-term benefit is mirrored by the extraordinary stability of the housing economy in Switzerland during the recent financial crisis. A 5-year blocking period was introduced for the sale of non-agricultural land and buildings, more stringent regulations for pension fund investors and stricter mortgage underwriting criteria. The taxation of real estate transaction has been tightened and relatively high progressive taxes on realized capital gains were also introduced. Those fiscal burdens are negatively related to the duration of property ownership which is another factor that mitigates speculation. In addition, the Swiss financial center implemented changes in governance, risk management and compliance. In particular, Swiss banks became more cautious and conservative about their credit lending. Properties would be financed up to a maximum of 80 per cent of their value, if the cost of owning did not exceed one third of a household's gross income (Bourassa et al., 2009).

The Swiss housing market is also well isolated from foreign investments. The acquisition of residential properties in Switzerland by foreigners is restricted due to the 'Lex Koller' legislation. The significance of this legislation became visible after it was recently loosened, allowing for the acquisition of holiday homes by foreigners and resulting in substantial price inflation in this sub-market. Another remarkable characteristic of the Swiss housing economy is its dominance by tenants. In this extent "(t)he Swiss housing market differs considerably from what one might expect based on the economic conditions of one of the world's wealthiest nations" (Werczberger, 1997, p. 337). Switzerland's home ownership rate at 34.6 per cent is the lowest among developed countries. As proposed by Bourassa and Hoesli (2006) this is primarily caused by high house prices relative to rents and relative to household incomes and wealth. Furthermore, discriminatory taxation of home owners and regulations that favor tenants provide further disincentives for house buyers. In comparison with the US, the Swiss system of income taxation is much less favorable to home ownership (Bourassa et al., 2009). For example, for annual taxation owners of residential properties must include to their income imputed rent, which constitutes 70 per cent of market rent. A further distinct difference from the US housing economy is the nature of the housing stock. As outlined by Bourassa et al. (2009), the share of multi-family houses accounts for around 70 per cent, which is twice as high as in the US, while the share of single-family houses, accounting for 23 per cent of the Swiss housing stock, is only fractional compared with the US (60 per cent). Obviously, the availability of the former type of housing stock plays an important role in the flat rental market, whereas single-family houses constitute a much less attractive category for rentals.

Figure 3 presents an international comparison of risk-return profiles for a selection of seventeen countries. ${ }^{2}$ It becomes obvious that Switzerland, Japan and Germany expose the

\footnotetext{
${ }^{2}$ Figure 2 has to be compared under the caveat that data on residential property prices are not strictly
} 
lowest standard deviation of house prices among all studied countries. If countries with positive growth rates in house price are considered, Switzerland clearly has the lowest level of volatility. Given its risk profile, it provides a high annual return of around 2.6 per cent.

\section{Literature Overview}

A standard approach in the literature expressed by Poterba (1984) is to model the housing market as an asset market. Case and Shiller (1990) notice, however, that the housing market is not very efficient and that it is possible to forecast house prices. They find that a change in real housing prices predicts its own change in the following year. Additional evidence in that respect comes from Malpezzi (1999) who rejects the random walk hypothesis for house prices. $^{3}$

Intuitively, housing demand is negatively related to interest rates as higher interest rates make investing in houses (by borrowing) more expensive and other interest-bearing assets more attractive. Viewed through the lens of asset pricing, an increase in mortgage interest payments lowers future returns on a house and, hence, lowers demand for this asset leading to a fall in prices. The influence of interest rates on house prices is, among other factors, formalized under the label of the user costs of housing. Employing this concept, Poterba (1984) argues that inflation - a substantial part of the real interest rate - reduces the effective cost of home ownership.

Kahn $(2008,2009)$ attributes the change in house prices to productivity growth. The channel through which productivity growth affects house prices is income. Productivity growth increases lead to current income growth and, if persistent, raise expectations for higher future income. As a consequence, the demand for housing rises and this increases the price of housing ceteris paribus.

On the demand side, it is important to incorporate the idea that demographics could substantially drive housing demand. Furthermore, housing demand rises sharply between the ages of 20 and 30 and declines slowly after the age of 40 (for example, Levin et al., 2009). Certain age cohorts (below 20 and above some upper threshold) have, therefore, little impact on the demand for housing.

On the supply side, construction activities depend on the profitability of house building and, hence, should be positively correlated with the level of real house prices. Because the market participants are forward looking, house prices should contain some (if not all) information about future developments in the market, including information about future construction activities. In an analysis of the UK housing market, Ball (2010) finds that

comparable across countries due to differences in definitions.

3 See also HM Treasury (2003): 'Housing, Consumption and EMU' for a detailed review. 
regulatory controls on the supply of housing results in the low responsiveness of housing supply to changes in market activity. It is likely that the sluggishness in the market causes a change in current housing supply to be correlated with past changes in supply. Remaining influences on the profitability of new house building include the costs of house building.

Housing demand is therefore defined by the following equation:

$$
\mathrm{D}=\mathrm{f}\left(\mathrm{P}, \mathrm{Y}, \mathrm{r}, \mathrm{X}_{\mathrm{D}}\right)
$$

where housing demand $(D)$ is a function of real house prices $(P)$, real income $(Y)$, real interest rates $(r)$ and a vector of other demand factors $\left(X_{D}\right)$ like demographics or expected return on housing.

$$
\mathrm{S}=\mathrm{f}(\mathrm{P}, \mathrm{Xs})
$$

Equation (2) states that the housing supply is a function of real house prices and a number of factors $(X s)$ that influence the profitability of house building like construction costs. We assume throughout the paper that the housing market is in equilibrium and derive from Equations (1) and (2) an expression for real house prices:

$$
\mathrm{P}=\mathrm{f}\left(\mathrm{Y}, \mathrm{r}, \mathrm{X}_{\mathrm{D}}, \mathrm{Xs}_{\mathrm{S}}\right)
$$

The empirical research in this area has a strong US focus. Poterba (1991) examines the changes in the construction costs, demographic factors and the real, after-tax cost of home ownership as possible determinants of shifts of demand and supply in the housing market. Case and Shiller (1990) study the persistence of price changes for single-family homes in U.S. cities. More recent research has investigated the markets of other countries. Examples of these studies are Meese and Nancy (2003) for the French market and Meen (2002) who looked at the British market. Cross-country studies usually focus on advanced economies, see Englund and Ioannides (1997) among others. For the Swiss housing market the list of academic publications is rather short. Bourassa and Hoesli (2006) identify the key determinants of the Swiss home ownership rate. Borowiecki (2009) models Swiss house prices and investigates the over-valuation of the market while Degen and Fischer (2010) investigate the impact of immigration on Swiss house prices.

\section{Data and Methodology}

\subsection{Data Description}


To model house prices we follow several articles in the literature that model housing supply and demand. Assuming that the market is in a state of equilibrium (i.e. supply equals demand), we regress house prices and construction activities on a set of independent variables that have been identified as drivers of supply and demand in previous studies. We also include lagged values of house prices and construction activities as independent variables, since these lags are often found to contain predictive power for current house price growth. Our measure for house price growth is derived from IAZI Swiss Exchange Private Real Estate Price Index. ${ }^{4}$ The index is based on information from banks, insurers and pension funds on actual changes of ownership. The house price index covers more than 60 per cent of the property transactions concluded in Switzerland. Because we are particularly interested in the real fluctuations in the housing market, we deflate our variables with the CPI deflator. As a proxy for construction activities we use the number of apartments under construction each year. ${ }^{5}$ Since the Swiss home ownership ratio is very low in an international context, apartments play a relatively large role and should therefore account for a substantial part of the residential property price variation. The data for apartment construction is obtained from the Swiss National Bank (SNB). We further augment our model with a couple of independent variables.

First, we include real domestic interest rates. Interest rates change the user cost of housing as discussed in the previous section and alter the attractiveness of investing in interest-bearing assets. For the key interest rate we use the Swiss discount rate. ${ }^{6}$ In order to account for demographic factors that could potentially drive house prices through the demand channel, we employ working age population (20-64); that is the age group of the overall population that has potentially the highest influence in determining housing demand. To incorporate the house price dependency on income and expectations of future income we include both, the development of Swiss GDP relative to the rest of the world and the unemployment rate as a measure of welfare. Using GDP as share of the world instead of regular GDP has the advantage that it captures relative movements in income. This is important since the underlying theories point to forward looking consumers that make decisions based on their expectations. Borrowing and lending by consumers, however, increasingly depends on the performance of a country relative to the world. This is caused by better access to international asset markets and employment of international investment opportunities for the benchmark of the domestic investor. If, for example, other countries are

\footnotetext{
4 The International Securities Identifying Number of this index is CH0030532342. From now on we refer to this index as 'house prices'.

${ }^{5}$ Records on construction of houses are not available. Data availability also restricts us from using a more sophisticated measure, such as the annual change in the number of square meters in residential property.

${ }^{6}$ Data was obtained from the Swiss National Bank statistics. Refer also to Table A1 in the Appendix for data sources of all remaining variables.
} 
growing faster, then capital would rather flow abroad instead of being invested domestically. Consequently, the inclusion of a measure of GDP relative to the world is required as it would capture these considerations better than an absolute GDP measure could. Unemployment, GDP and CPI data come from the IMF WEO database which collects its information from the national authorities.

The housing supply is expected to be positively related to the profitability of house building and, hence, positively correlated to the level of real house prices. This relationship could, however, be distorted in the short-run due to the sluggish nature of housing supply. Hence, we also include two lags of past changes in construction activities in our regressions. Remaining influences on the profitability of new house building include the construction cost. These costs are subsumed in the lagged house prices (that capture changes in the prices of land) and in an additional variable that we include - the CPI adjusted change in construction prices. As a construction price index we use the construction cost index for residential buildings provided by the Swiss National Bank. The selected data set covers the time period from 1990 to 2009 on an annual basis. Table 1 gives a description of the time series.

\subsection{Empirical Setup}

The results from unit root testing of the underlying variables, which are based on the augmented Dickey-Fuller (ADF) and Phillips-Perron (PP) tests, are presented in Table 2. The overall results are fairly concurrent with previous empirical findings. Both tests provide some indication that all variables are stationary, except interest rates and population growth. ${ }^{7}$ Due to the relatively low number of observations stationarity tests lack power. It is, therefore, difficult to distinguish between stationary and non-stationary time periods. If a longer data series of population was employed, the tests would suggest integration of order one. Building on those results and considering recent empirical research (e.g. Oikarinen 2007) we assume real interest rates to be integrated of order zero. All other variables we assume to be integrated of order one and hence we employ their growth rates. Nonetheless, the interpretation of the relationship between real interest rates and house prices should come with some caution since the real interest rates have fallen over time and, thus, exhibit a time trend. Both the augmented Dickey-Fuller and the Philipps-Perron test indicate nonstationarity of the real interest rates. This is not so much of a problem in the regression with the change in construction activities as a dependent variable - because this variable is highly stationary. But due to the weak stationarity of the change in the CPI adjusted change in house prices, the estimates might contain some noise because of the underlying time trends.

We complement the above analysis with an investigation of breaks in the housing price

\footnotetext{
${ }^{7}$ For population growth the null hypothesis that the variable contains a unit root is however somewhat close to not being rejected ( $p$-value $<0.16$ ).
} 
series and compute an innovational outlier unit root test that allow for two structural breaks (see Clemente et al., 1998). The emerging picture is presented in Appendix 2. The series is found to contain two breaks at years 1994 and $2005 .{ }^{8}$ The structural break at 1994 can presumably be explained by the introduction of construction subsidies by Swiss authorities in response to the housing crisis at the start of 1990. The subsidies to the extent of over $6 \mathrm{bn}$ USD led to a construction boom and ended with a massive over-supply around the year 1994 (Credit Suisse, 2000). The structural break at 2005 presumably coincides with the Free Movement of Persons from the EU/EFTA, which was introduced three years earlier. With the facilitation of migration, there resulted large migration inflows into Switzerland, leading to population growth of up to around 1 per cent. None of the structural breaks coincide with the recent global recession, which provides some indication of the robustness of the Swiss housing economy. Given that the data set ends in 2009, this, however, only provides tentative evidence. In addition, based on the conducted unit root test we can conclude the necessity of including all regressions' additional control variables that take account of the structural breaks.

As some of the variables in our system are integrated of the same order I(1), testing for cointegration may be desirable. The likelihood ratio trace test fails however to reject the null hypothesis of no cointegration. Similarly, the maximum eigenvalue statistic cannot reject the null hypothesis of no cointegration. As the results point to the absence of a cointegration relationship, we refrain from constructing a vector error correction model and estimate a vector autoregressive model (VAR). Given the aim of this research and in order to keep the estimation feasible we endogenize two variables: house prices and construction activity. Construction price changes, interest rates, population dynamics, relative GDP growth and, in some specifications, changes in unemployment are allowed only for an exogenous impact on the model. We follow Oikarinen (2009) in that we assume that interest rate changes are transmitted to the economy with a lag. We choose the number of lags based on lag order selection statistics. According to the three main information criteria (i.e. AIC, HQIC and SBIC) two lagged changes of the dependent variables should be included.

Hence, the VAR takes the following form: ${ }^{9}$

$$
\begin{aligned}
& \Delta \mathrm{hp}_{-} \mathrm{c}_{\mathrm{t}}=\beta_{1} \Delta \mathrm{hp}_{-} \mathrm{c}_{\mathrm{t}-1}+\beta_{2} \Delta \mathrm{hp} \mathrm{c}_{\mathrm{t}-2}+\beta_{3} \Delta \text { constrt }-1+\beta_{4} \Delta \text { constrt-2 }+ \\
& +\beta_{5} \Delta \mathrm{cp}_{-} \mathrm{c}_{\mathrm{t}}+\beta_{7} \operatorname{rir} \mathrm{r}-1+\beta_{8} \Delta \mathrm{pop}_{\mathrm{t}}+\beta_{9} \Delta \mathrm{gdp} / \mathrm{w}, \mathrm{t}+\beta_{10} \Delta \mathrm{unempl}_{\mathrm{t}}+\mathrm{u}_{\mathrm{hp}, \mathrm{t}}
\end{aligned}
$$

\footnotetext{
${ }^{8}$ A very similar picture emerges if the additive outlier unit root test is used. The breaks would occur at 1994 and 2006 (results not reported).

${ }^{9}$ The description of the variables can be found in Table A1 in the Appendix.
} 


$$
\begin{aligned}
\Delta \text { constr }_{\mathrm{t}}= & \gamma_{1} \Delta \mathrm{hp}_{-} \mathrm{ct}_{\mathrm{t}-1}+\gamma_{2} \Delta \mathrm{hp} \_\mathrm{ct}_{\mathrm{t}-2}+\gamma_{3} \Delta \operatorname{constr}_{\mathrm{t}-1}+\gamma_{4} \Delta \operatorname{constr}_{-2}+ \\
& +\gamma_{5} \Delta \mathrm{cp}_{-} \mathrm{c}_{\mathrm{t}}++\gamma_{6} \operatorname{rir} \operatorname{rir}_{-1}+\gamma_{7} \Delta \operatorname{pop}_{\mathrm{t}}+\gamma_{8} \Delta \mathrm{gdp}_{/ \mathrm{w}, \mathrm{t}-}+\beta_{10} \Delta \text { unempl }_{\mathrm{t}}+\mathrm{u}_{\mathrm{constr}, \mathrm{t}}
\end{aligned}
$$

\section{Results}

The estimation results from equations (4a) and (4b) are reported in columns 1 to 6 of Table 3 . We run three different specifications. Columns 1 and 2 show the results of our first specification that includes all fundamental variables except for unemployment, as it might be potentially endogenous to the construction price index or working age population. The estimation reveals that a one per cent increase in the lagged change in the construction price is associated with an increase of around 0.3 per cent in the house price index. This potentially reflects that an increase in construction price growth decreases the profitability of construction and therefore drives up housing prices. A one percentage point higher lagged real interest rate is associated with a decrease in the price of houses of around 2 per cent. This possibly indicates that a decrease in the interest rate makes housing more affordable and therefore drives up the demand for it. House prices are found to be most responsive to a change in demand-related demographic factors: a one per cent increase in the working age population is associated with a 7.6 per cent increase in house prices in the following year. Also, when the Swiss economy is growing relatively faster than the world's economies, house prices tend to increase. The estimated coefficient implies that a one per cent increase in Switzerland's growth relative to the world is associated with a rise in house price of approximately 0.7 per cent. A one per cent increase in house prices two years before is associated with a decrease of approximately the same magnitude of current house prices. This might be an indication that the Swiss housing market is indeed inefficient. Moreover, the coefficient could also reflect the stability of the housing market: acceleration or slow down in house price inflation will revert after two years. Furthermore, the significance of the other lagged endogenous variable suggests that house prices can be forecast. A change in the first lag of the construction activity is negatively correlated with the change in house prices; the coefficient is, however, equal to 0.09 and thus relatively small. Moreover, a change in the second lag of the same variable has the opposite coefficient, suggesting that the house price adapts quickly to any changes in housing supply. This result could also be leveraged by the protected and highly regulated character of the Swiss housing economy as well as the constrained supply.

On the supply side, we find that a one per cent increase in the change in construction prices results in a 1.8 per cent decrease in construction activities. Construction activities are also negatively related to lagged real interest rates: a one percentage point increase in the 
interest rate corresponds with a 6 per cent lower construction activity. ${ }^{10}$ Once again, the strongest effect comes from population changes. A one per cent increase in the working age population leads to a 17 per cent increase in construction activity. ${ }^{11}$ The results further indicate that relative income growth is positively related to the change in the construction activities. The causal relationship between those two variables is, however, particularly unclear. On the one hand, higher relative income could lead to higher construction activity. On the other hand, however, bustling construction activity could stimulate GDP. An increase in the price of houses has, in the short-run, a negative association with the number of apartments under construction. This relationship could possibly originate in the increased incentive to sell the property to the market earlier. It is likely that a rising house price stimulates the developers to go for earlier sales of the housing units that are under construction, but not yet finished. The positive coefficient on the lagged construction activity indicates the delayed responses of the construction firms to any changes in the market. It requires time, for example, to decrease the employment or liquidate unused machinery.

Next we attempt to investigate how cyclicality affects the findings presented above. In the baseline specification cyclicality might not be adequately captured by some of the used variables, for example, if variations in the GDP were synchronized across countries, relative GDP would not change. Therefore, we extend the baseline model by including the unemployment rate and report the results in columns 3 and 4 of Table 3 . The point estimate on the additional variable is negative albeit outside the usual confidence levels. For the house price specification the $p$-value of the unemployment coefficient is equal to around 0.078 . The result indicates that an increase in the unemployment rate by one percentage point leads to a roughly one per cent decrease in house prices. Given that prices are linked to unemployment through the Phillips curve, this is not surprising. It can be also observed that the inclusion of the unemployment rate decreases the estimate on the construction price, which is now not significant anymore at the conventional confidence levels. This is presumably caused by the fact that labor costs constitute a relatively large share of the construction cost index.

An question which arises here is whether and to what extent crises influence the Swiss housing economy. Ideally we would perform an out of sample analysis and provide a separate investigation for the years of crisis. Alternatively, one could also obtain interaction terms between all included independent variables and the periods of a crisis. Both methods are, however, unattainable in this study, due to the very short data series of only 20 annual observations. We therefore adopt a third approach and measure the difficult years of a crisis

\footnotetext{
${ }^{10}$ We also employed current interest rates. The sign of the coefficient on this variable is equivalent to the results of Table 3. However, these results are not significant suggesting some sluggishness in the reaction of house prices.

${ }^{11}$ Table 1 indicates that the average growth rate in population over the sample period was only 0.77 per cent.
} 
with a dummy variable. In the third specification we include an indicator function (Crisis) that takes the value one for the years when a crisis occurred in Switzerland and zero otherwise. ${ }^{12}$ It is interesting to observe in columns 5 and 6 that the estimated coefficient on the crisis variable is negligible in size and clearly insignificant. Furthermore, it can be observed that the point estimates on all remaining variables remain basically unchanged in sign, size and significance. Based on these results, one can draw the tentative conclusion that the studied crises do not affect the Swiss housing market through any channels other than that which is included in the relevant specifications.

The estimated coefficients between the dependent and the independent variables are straightforward to interpret and broadly in line with what one would expect. The explanatory power of the models, as suggested by the $\mathrm{R}^{2}$ statistic, is very high. The information criteria (i.e. AIC, SBIC and HQIC) suggest that the first specification, in which we exclude unemployment and the crisis dummy, is the preferred model. Based on the baseline specification we depict in Figures 4 and 5 the estimated and actual house price and construction activity developments, respectively. It is reassuring to observe that the model tracks the actual changes in house prices and construction activity very closely.

\section{Conclusion}

In this research it is posited that a high degree of protectionism of a national housing economy could lead to its stability. This study describes the unique features of the Swiss housing economy and demonstrates efforts to compare it with other housing economies. Furthermore, the determinants of house price and construction activity are modeled and the associated dynamics are investigated. We cover a very interesting period of time, from 1990 to 2009 , in which two substantial economic crises occurred. Focusing on this period allows for an investigation of whether and how the Swiss housing market becomes affected by economic turbulence. The drawback of the conducted econometric analysis is its short time span and hence the results have to be interpreted with a word of caution.

We find that house prices are positively associated with construction prices, working age population as well as GDP and are negatively associated with interest rates. Construction activity is positively related to working age population and GDP and has a negative relationship with construction costs and interest rates. Based on our model the predictions correspond well with actual data and indicate that the model is well specified. The findings are consistent with the dominant view in the literature that the housing market is not very efficient. Lagged house price changes are able to predict future house price growth. Similarly,

\footnotetext{
${ }^{12}$ We set the indicator function equal to one for the duration of the crisis of the early 1990s (i.e. 19901994) and the recent global financial crisis (i.e. 2006-2009). The results are robust to numerous alterations of those particular years.
} 
past changes in construction activities contain information pertinent to current construction activities.

While the study does not explicitly link the degree of protectionism with house price stability, it provides some indication of the existence of a relationship between those two. The Swiss housing price is in accordance with fundamentals and there is no sign of over-valuation. The determinants of housing price and construction activity are consistent with theory and previous empirical studies. There was also no decline in the value of the Swiss housing market in recent years, whereas most housing economies experienced substantial drops. The national average asking price for residential properties was down by 43 per cent in Ireland from its unrivalled high of 2007, 20 per cent in the United Kingdom, 13 per cent in Spain and experienced large decreases among most developed economies (Global Property Guide, 2011). Over a similar time period, the Swiss house price rose steadily by up to 5 per cent annually.

The reasons for the observed stability of the Swiss housing economy can only be speculated. It is possible that large immigration flows of the most recent years have, to some extent, counteracted the negative spillover effects of the international financial turbulence. Nonetheless, even if the growth of the working-age population of the last five years is considered (equal to just above 1 per cent), in light of Degen and Fischer (2010) and also the results presented in this research, the impact on house prices would be expected to be in the region of around 3.7 to 8.4 per cent and could hardly prevent double digit house price drops that have been internationally observed. Of greater importance perhaps are the existing policies that protect the Swiss housing market from any greater turbulence. Heavily restricted speculation, due to legislative as well as fiscal regulations, in combination with constraints imposed on foreign acquisition might have been among the most important determinants of the observed stability. In addition, de-incentivized home-ownership as well as substantial supportive and protective policies for tenants have most likely prevented over-borrowing to some extent and hence resulted in the financial stability of Swiss households relative to other countries. Finally, the conservative lending practices of the Swiss banking sector have presumably prevented the kind of over-consumption which has occurred in other countries. Future research and country-specific case studies are required in order to investigate what kinds of regulations would be particularly meaningful and beneficial to the stability of a housing economy. 


\section{References}

[1] M. Ball. Planning delay and the responsiveness of english housing supply. Urban Studies, 48(2):349-362, 2011.

[2] K. J. Borowiecki. The determinants of house prices and construction: An empirical investigation of the swiss housing economy. International Real Estate Review, 12(3):193-220, 2009.

[3] S. Bourassa and M. Hoesli. Why do the swiss rent? The Journal of Real Estate Finance and Economics, 40(3):286-309, 2010.

[4] S.C. Bourassa, M. Hoesli and D. Scognamiglio. Housing Finance, Prices and Tenure in Switzerland. Swiss Finance Institute Research Paper Series, 09(16), 2009.

[5] K. E. Case and R. J. Shiller. The efficiency of the market for single-family homes. American Economic Review, 79(1):125-37, 1989.

[6] J. Clemente, A. Montanes, and M. Reyes. Testing for a unit root in variables with a double change in the mean. Economics Letters, 59:175-182, 1998.

[7] Credit Suisse. Der Schweizer Immobilienmarkt. Fakten Und Trends. Credit Suisse Economic Research, Mat.-Nr. 1511451, 5, 2000.

[8] K. Degen and A. M. Fischer. Immigration and swiss house prices. CEPR Discussion Paper, 7583, 2010.

[9] P. Englund and Y. M. Ioannides. House price dynamics: An international empirical perspective. Journal of Housing Economics, 6(2):119-136, 1997.

[10] E. L. Glaeser, J. Gyourko, and R. E. Saks. Why have housing prices gone up? The American Economic Review, 95(2):329-333, 2005.

[11] Global Property Guide. http://www.globalpropertyguide.com/ (accessed September 2011), 2011.

[12] J. A. Kahn, What Drives Housing Prices? FRB of New York Staff Report, No. 34, 2008.

[13] J. A. Kahn, Productivity Swings and Housing Prices. Current Issues in Economics and Finance, 15(3):1-8, 2009.

[14] R. J. Lawrence. Switzerland. In Balchin, P. (Ed) Housing Policy in Europe, (London, Routledge) pp36-50, 1996.

[15] E. Levin, A. Montagnoli, and R. E. Wright. Demographic change and the housing market: Evidence from a comparison of Scotland and England. Urban Studies, 46(1):27-43, 2009.

[16] S. Malpezzi. A simple error correction model of house prices. Journal of Housing Economics, 8(1):27-62, 1999.

[17] G. Meen. The time-series behavior of house prices: A transatlantic divide? Journal of Housing Economics, 11(1):1-23, 2002.

[18] R. Meese and N. Wallace. House price dynamics and market fundamentals: The parisian housing market. Urban Studies, 40(5-6):1027-1045, 2003.

[19] E. Oikarinen. Studies on Housing Price Dynamics. Turku Working Paper Series, A-9, 2007.

[20] E. Oikarinen. Interaction between housing prices and household borrowing: The finnish case. Journal of Banking \& Finance, 33(4):747-756, 2009. 
[21] J. M. Poterba. Tax subsidies to owner-occupied housing: An asset-market approach. The Quarterly Journal of Economics, 99(4):729-52, 1984.

[22] J. M. Poterba. House price dynamics: The role of tax policy. Brookings Papers on Economic Activity, 22(2):143-204, 1991.

[23] E. Werczberger. Home Ownership and Rent Control in Switzerland. Housing studies, 12(3):337$353,1997$. 
Tables

Table 1. Descriptive Statistics.

\begin{tabular}{cccccc}
\hline & Obs & Mean & Std. Dev. & Min & Max \\
\hline$\Delta$ hp_c & 20 & $-0.35 \%$ & $3.34 \%$ & $-6.33 \%$ & $8.29 \%$ \\
$\Delta$ constr & 20 & $1.19 \%$ & $10.39 \%$ & $-15.74 \%$ & $21.04 \%$ \\
$\Delta$ cp_c & 20 & $-0.47 \%$ & $2.73 \%$ & $-7.73 \%$ & $3.47 \%$ \\
rir & 20 & $3.12 \%$ & $1.39 \%$ & $1.01 \%$ & $5.72 \%$ \\
$\Delta$ pop & 20 & $0.77 \%$ & $0.43 \%$ & $0.04 \%$ & $1.67 \%$ \\
\hline gdp $/ \mathrm{w}$ & 20 & $-2.14 \%$ & $1.84 \%$ & $-8.86 \%$ & $0.58 \%$ \\
\hline
\end{tabular}

Note: Mean, Std. Dev., Min and Max values are in percentages.

Table 2. Stationarity Tests.

\begin{tabular}{|c|c|c|c|c|c|c|}
\hline & \multicolumn{2}{|c|}{$1 \mathrm{lag}$} & \multicolumn{2}{|c|}{2 lags } & \multicolumn{2}{|c|}{3 lags } \\
\hline & $\mathrm{ADF}$ & PP & $\mathrm{ADF}$ & PP & $\mathrm{ADF}$ & PP \\
\hline$\Delta h p \_c$ & -2.961 & $-13.146^{\star *}$ & -2.302 & $-12.891^{* *}$ & -2.055 & -12.403 \\
\hline$\Delta$ constr & $-3.794^{* * *}$ & $-22.882^{* * *}$ & $-3.152^{* *}$ & $-21.738^{\star * *}$ & -2.317 & $-19.851^{* * *}$ \\
\hline$\Delta \mathrm{cp} \_\mathrm{c}$ & $-3.627^{\star *}$ & $-14.622^{* *}$ & -1.867 & -12.282 & -2.929 & -11.197 \\
\hline Rir & -0.749 & -3.279 & -0.343 & -3.627 & -0.911 & -3.177 \\
\hline$\Delta$ pop & -2.124 & -8.563 & -2.039 & -8.570 & -1.948 & -8.681 \\
\hline$\Delta \operatorname{gdp} / \mathrm{w}$ & $-4.084^{* * *}$ & $-21.981^{* * *}$ & $-2.992^{* *}$ & $-19.903^{* * *}$ & -2.396 & $-18.095^{* * *}$ \\
\hline$\Delta$ unemp. & $-3.973^{* * *}$ & $-16.330^{* *}$ & -2.581 & $-14.968^{* *}$ & -2.833 & $-13.426^{\star *}$ \\
\hline
\end{tabular}


Table 3. House Prices and Construction Activity.

\begin{tabular}{|c|c|c|c|c|c|c|}
\hline & $\begin{array}{c}(1) \\
\Delta \mathrm{hp} \_\mathrm{ct}\end{array}$ & $\begin{array}{c}(2) \\
\Delta \text { constrt }^{2}\end{array}$ & $\begin{array}{c}(3) \\
\Delta \mathrm{hp} \_\mathrm{ct}\end{array}$ & $\begin{array}{c}(4) \\
\Delta \text { constrt }\end{array}$ & $\begin{array}{c}(5) \\
\Delta \mathrm{hp} \_\mathrm{C}_{t}\end{array}$ & $\begin{array}{c}(6) \\
\Delta \text { constrt }^{2}\end{array}$ \\
\hline$\Delta \mathrm{hp} \_\mathrm{ct}-1$ & $\begin{array}{c}-0.0248 \\
(0.112)\end{array}$ & $\begin{array}{c}-1.532^{* * *} \\
(0.386)\end{array}$ & $\begin{array}{r}-0.0422 \\
(0.105)\end{array}$ & $\begin{array}{c}-1.502^{* * *} \\
(0.381)\end{array}$ & $\begin{array}{l}-0.0426 \\
(0.0992)\end{array}$ & $\begin{array}{c}-1.502^{\star * *} \\
(0.381)\end{array}$ \\
\hline$\Delta \mathrm{hp} \_\mathrm{ct}-2$ & $\begin{array}{c}-1.048^{* * *} \\
(0.146)\end{array}$ & $\begin{array}{l}-0.318 \\
(0.502)\end{array}$ & $\begin{array}{c}-0.941^{\star * *} \\
(0.149)\end{array}$ & $\begin{array}{l}-0.501 \\
(0.540)\end{array}$ & $\begin{array}{c}-0.920^{* * *} \\
(0.141)\end{array}$ & $\begin{array}{l}-0.499 \\
(0.543)\end{array}$ \\
\hline$\Delta$ constrt ${ }_{-1}$ & $\begin{array}{c}-0.0913^{\star *} \\
(0.0418)\end{array}$ & $\begin{array}{c}0.420^{* * *} \\
(0.144)\end{array}$ & $\begin{array}{l}-0.0767 \\
(0.0398)\end{array}$ & $\begin{array}{c}0.394^{* * *} \\
(0.145)\end{array}$ & $\begin{array}{l}-0.0691 \\
(0.0381)\end{array}$ & $\begin{array}{c}0.395^{\star \star *} \\
(0.146)\end{array}$ \\
\hline$\Delta$ constrt $^{2} 2$ & $\begin{array}{l}0.136^{\star * *} \\
(0.0337)\end{array}$ & $\begin{array}{l}-0.182 \\
(0.116)\end{array}$ & $\begin{array}{l}0.135^{\star * *} \\
(0.0314)\end{array}$ & $\begin{array}{l}-0.180 \\
(0.114)\end{array}$ & $\begin{array}{l}0.126^{* * *} \\
(0.0303)\end{array}$ & $\begin{array}{l}-0.181 \\
(0.116)\end{array}$ \\
\hline$\Delta \mathrm{cp} \_\mathrm{ct}_{\mathrm{t}}$ & $\begin{array}{c}0.299^{\star * *} \\
(0.116)\end{array}$ & $\begin{array}{c}-1.788^{* * *} \\
(0.398)\end{array}$ & $\begin{array}{l}0.0925 \\
(0.159)\end{array}$ & $\begin{array}{c}-1.433^{* *} \\
(0.579)\end{array}$ & $\begin{array}{c}0.146 \\
(0.155)\end{array}$ & $\begin{array}{c}-1.429^{\star *} \\
(0.594)\end{array}$ \\
\hline rirt-1 & $\begin{array}{c}-0.0200^{* * *} \\
(0.00232)\end{array}$ & $\begin{array}{c}-0.0604^{* * *} \\
(0.00799)\end{array}$ & $\begin{array}{c}-0.0200^{* * *} \\
(0.00216)\end{array}$ & $\begin{array}{c}-0.0604^{\star * *} \\
(0.00786)\end{array}$ & $\begin{array}{c}-0.0198^{* * *} \\
(0.00205)\end{array}$ & $\begin{array}{c}-0.0604^{\star * *} \\
(0.00787)\end{array}$ \\
\hline$\Delta \mathrm{pop}_{\mathrm{t}}$ & $\begin{array}{c}7.585^{\star \star *} \\
(1.132)\end{array}$ & $\begin{array}{c}16.94^{\star \star *} \\
(3.899)\end{array}$ & $\begin{array}{c}7.742^{\star \star *} \\
(1.057)\end{array}$ & $\begin{array}{c}16.67^{\star \star *} \\
(3.847)\end{array}$ & $\begin{array}{c}6.891^{* * *} \\
(1.150)\end{array}$ & $\begin{array}{c}16.61^{* \star *} \\
(4.415)\end{array}$ \\
\hline$\Delta \mathrm{gdp} / \mathrm{w}, \mathrm{t}$ & $\begin{array}{c}0.692^{\star * *} \\
(0.170)\end{array}$ & $\begin{array}{c}2.382^{* * *} \\
(0.586)\end{array}$ & $\begin{array}{c}0.563^{\star \star *} \\
(0.174)\end{array}$ & $\begin{array}{c}2.604^{* * *} \\
(0.635)\end{array}$ & $\begin{array}{c}0.562^{\star \star *} \\
(0.165)\end{array}$ & $\begin{array}{c}2.604^{* * *} \\
(0.635)\end{array}$ \\
\hline$\Delta$ unemp $_{\mathrm{t}}$ & & & $\begin{array}{c}-0.00968 \\
(0.00549)\end{array}$ & $\begin{array}{c}0.0166 \\
(0.0200)\end{array}$ & $\begin{array}{c}-0.00908 \\
(0.00522)\end{array}$ & $\begin{array}{c}0.0167 \\
(0.0200)\end{array}$ \\
\hline crisis & & & & & $\begin{array}{c}0.00909 \\
(0.00603)\end{array}$ & $\begin{array}{c}0.000673 \\
(0.0232)\end{array}$ \\
\hline constant & $\begin{array}{c}0.0202^{* *} \\
(0.00898)\end{array}$ & $\begin{array}{l}0.107^{\star * *} \\
(0.0309)\end{array}$ & $\begin{array}{c}0.0162^{*} \\
(0.00866)\end{array}$ & $\begin{array}{l}0.114^{\star * *} \\
(0.0315)\end{array}$ & $\begin{array}{c}0.0188^{\star *} \\
(0.00840)\end{array}$ & $\begin{array}{l}0.114^{\star * *} \\
(0.0322)\end{array}$ \\
\hline R2 & 0.88 & 0.85 & 0.90 & 0.86 & 0.91 & 0.86 \\
\hline AIC & -7.995 & -7.995 & -8.087 & -8.087 & -8.026 & -8.026 \\
\hline HQIC & -7.801 & -7.801 & -7.873 & -7.873 & -7.793 & -7.793 \\
\hline SBIC & -6.999 & -6.999 & -6.991 & -6.991 & -6.831 & -6.831 \\
\hline Observation & 20 & 20 & 20 & 20 & 20 & 20 \\
\hline
\end{tabular}

Note: Standard errors in parentheses. All specifications contain controls for the years 1994 and 2005 at which a structural break in the house price series occurred. The Crisis dummy takes the value one for the years 1990 to 1994 and 2006 to 2009, and zero otherwise. Description of remaining variables is presented in Table A1 in the Appendix. ${ }^{* * *} \mathrm{p}<0.01,{ }^{* *} \mathrm{p}<0.05$. 


\section{Figures}

Figure 1. Property Price Index and House Price Changes.

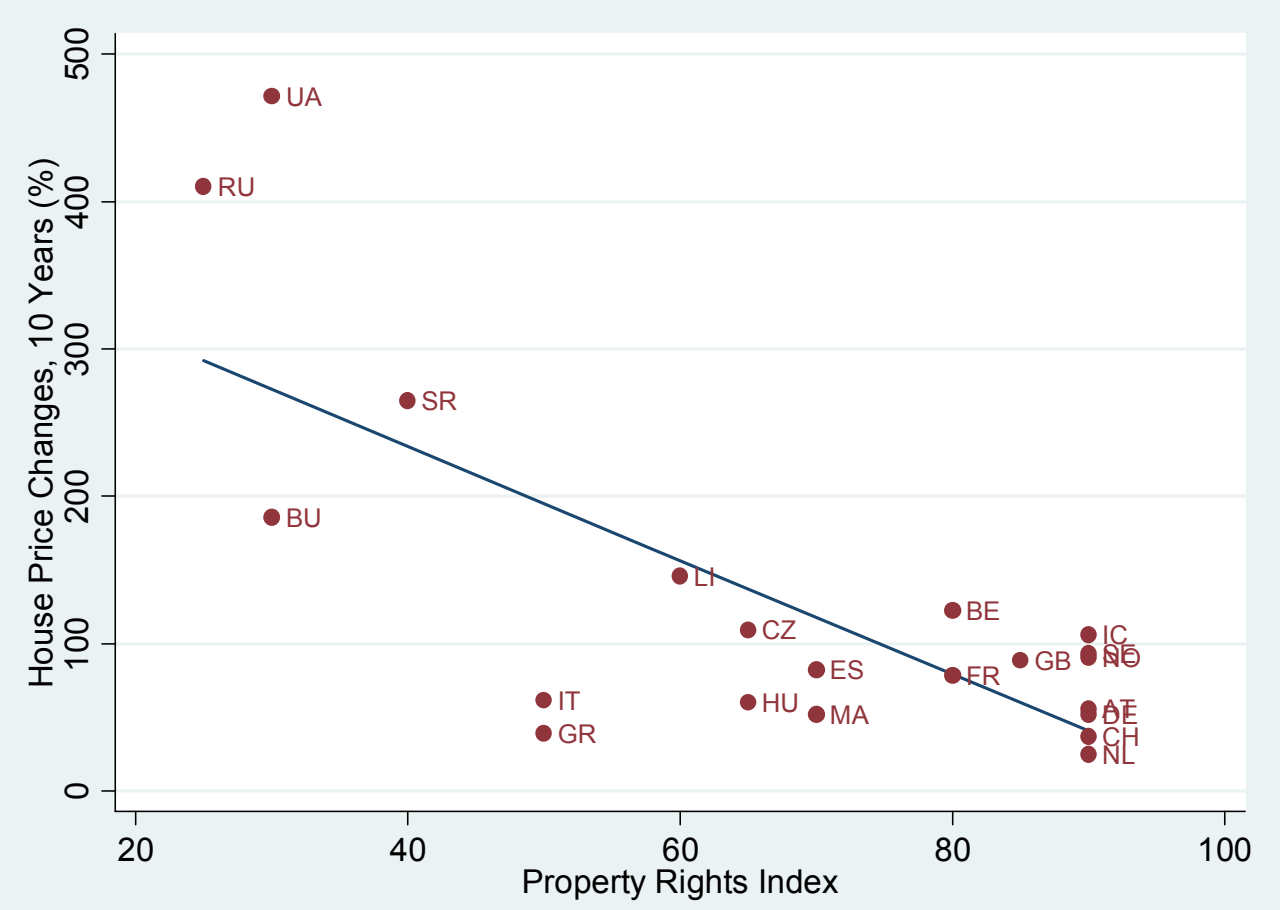

Source: Property Rights Index and House Price Changes are obtained from Global Property Guide (2011), for Austria (AT), Belgium (BE), Bulgaria (BU), Czech Republic (CZ), Germany (DE), France (FR), Greece (GR), Hungary (HU), Iceland (IC), Italy (IT), Lithuania (LI), Malta (MA), Netherlands (NL), Norway (NO), Russia (RU), Serbia (SR), Spain (ES), Sweden (SE), Switzerland (CH), Ukraine (UA) and United Kingdom (GB). 
Figure 2. Swiss house price 1982 to 2010.

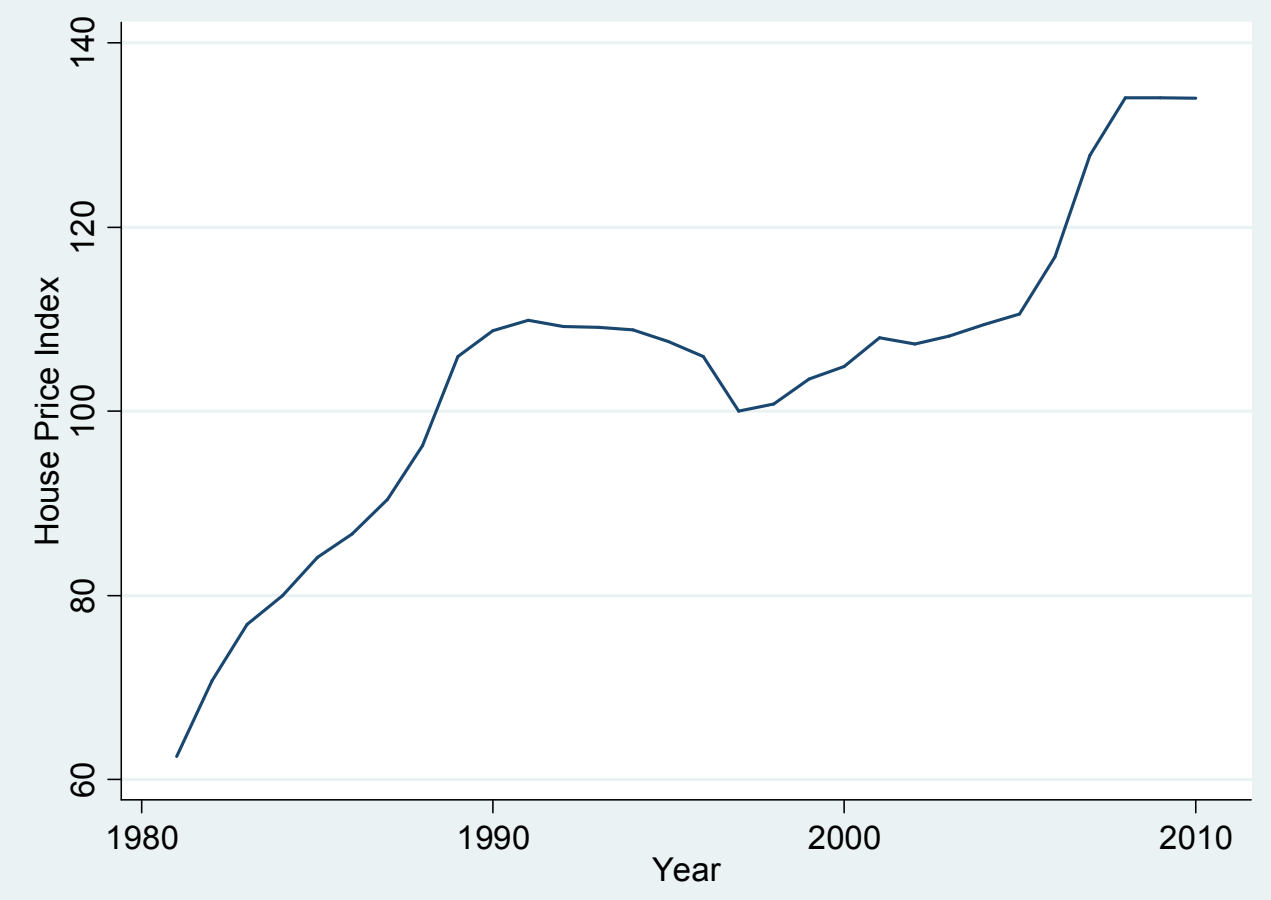

Source: SWX IAZI Private Real Estate Price Index. 
Figure 3. Risk-return profiles of international housing economies.

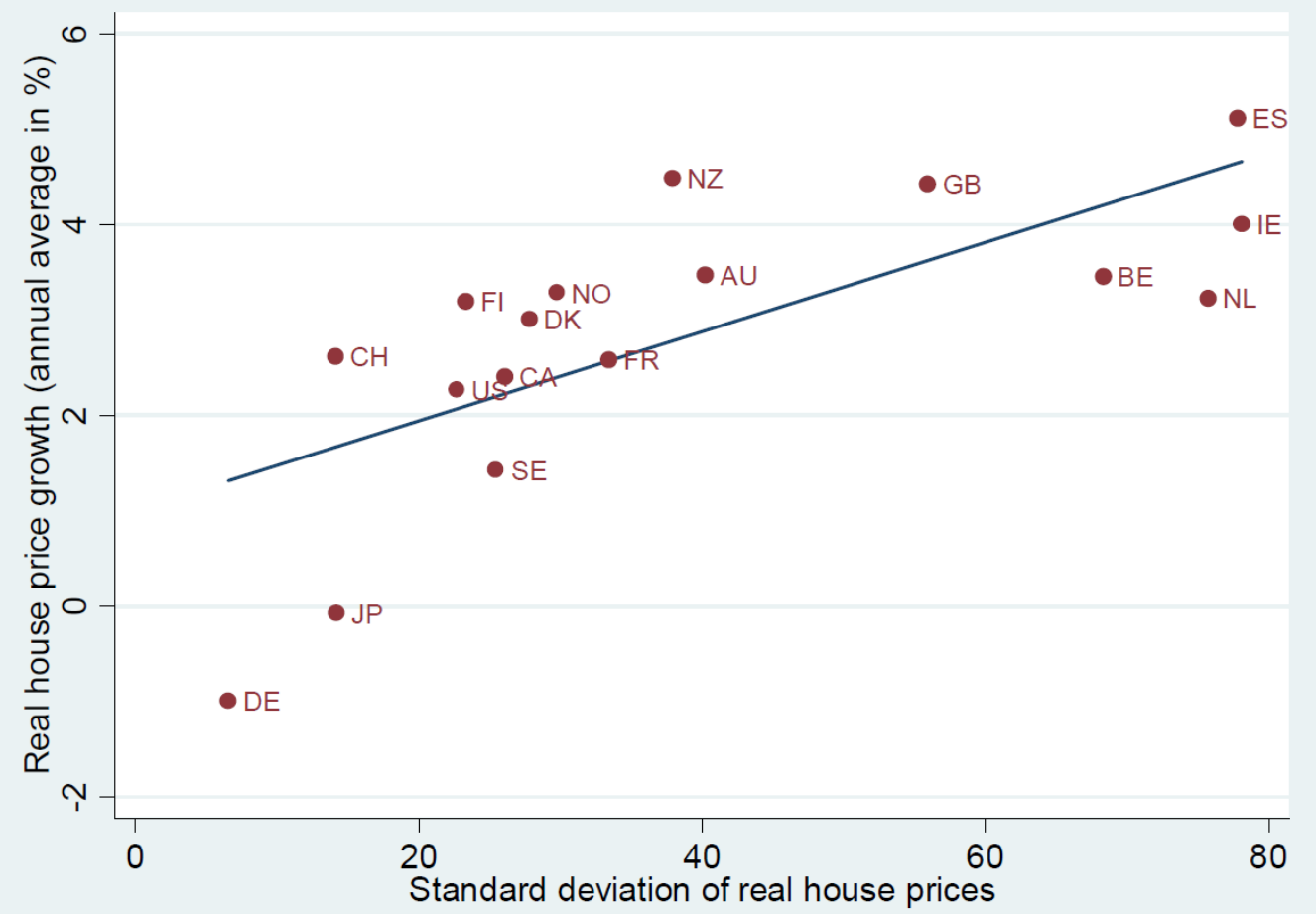

Source: Borowiecki (2009). Note: Switzerland (CH) is based on the inflation adjusted SWX IAZI Private Real Estate Price Index. BIS calculation based on national data is employed for all remaining countries, that is Australia (AU), Belgium (BE), Canada (CA), Denmark (DK), Finland (FI), France (FR), Germany (DE), Ireland (IE), Italy (IT), Japan (JP), Netherlands (NL), New Zealand (NZ), Norway (NO), Spain (ES), Sweden (SE), Switzerland (CH), United Kingdom (GB) and United States (US)). The covered time period is 1981 to 2006. 
Figure 4. Predicted and actual house price growth.

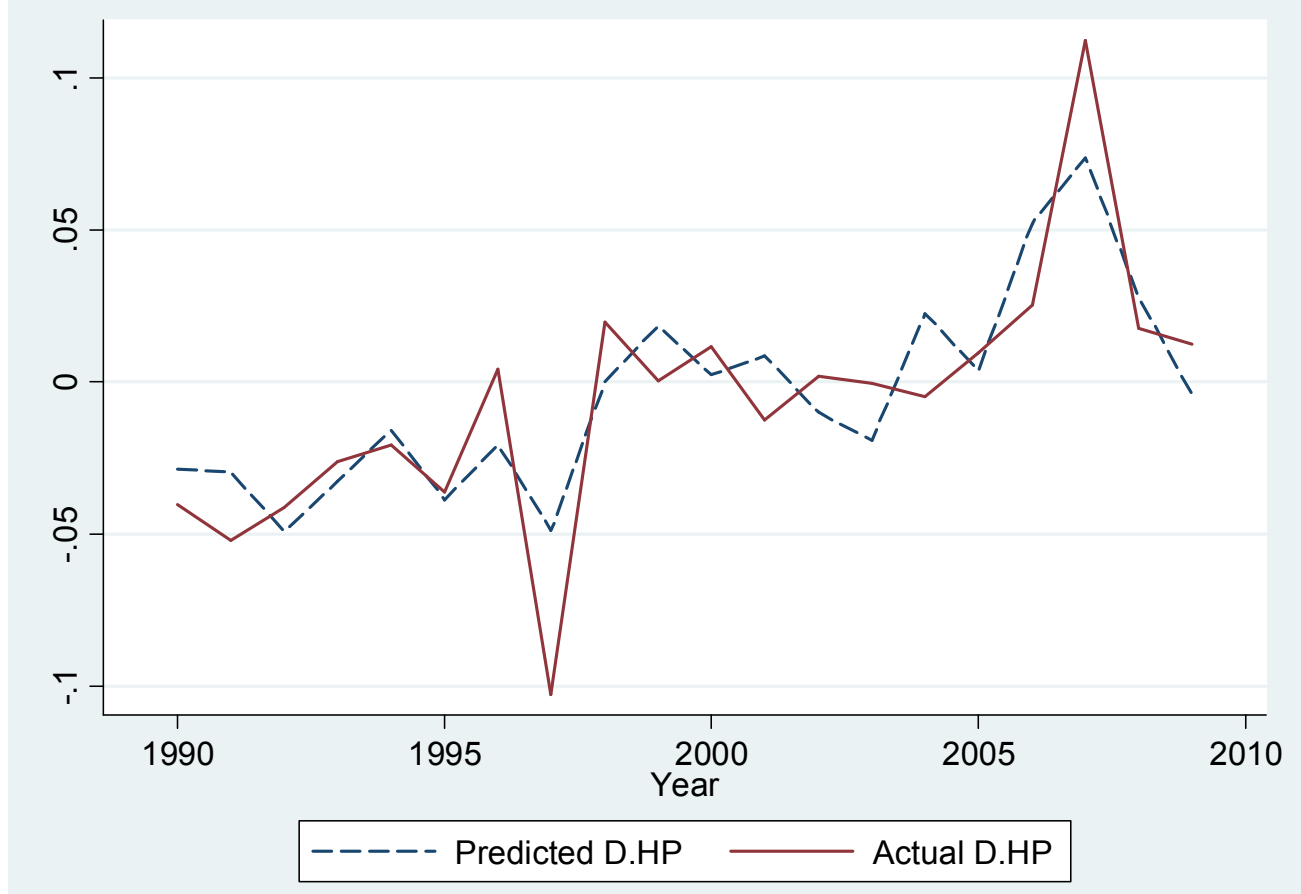

Note: Predicted house price growth is based on the specification presented in column (1), Table 3. 
Figure 5. Predicted and actual construction activity growth.

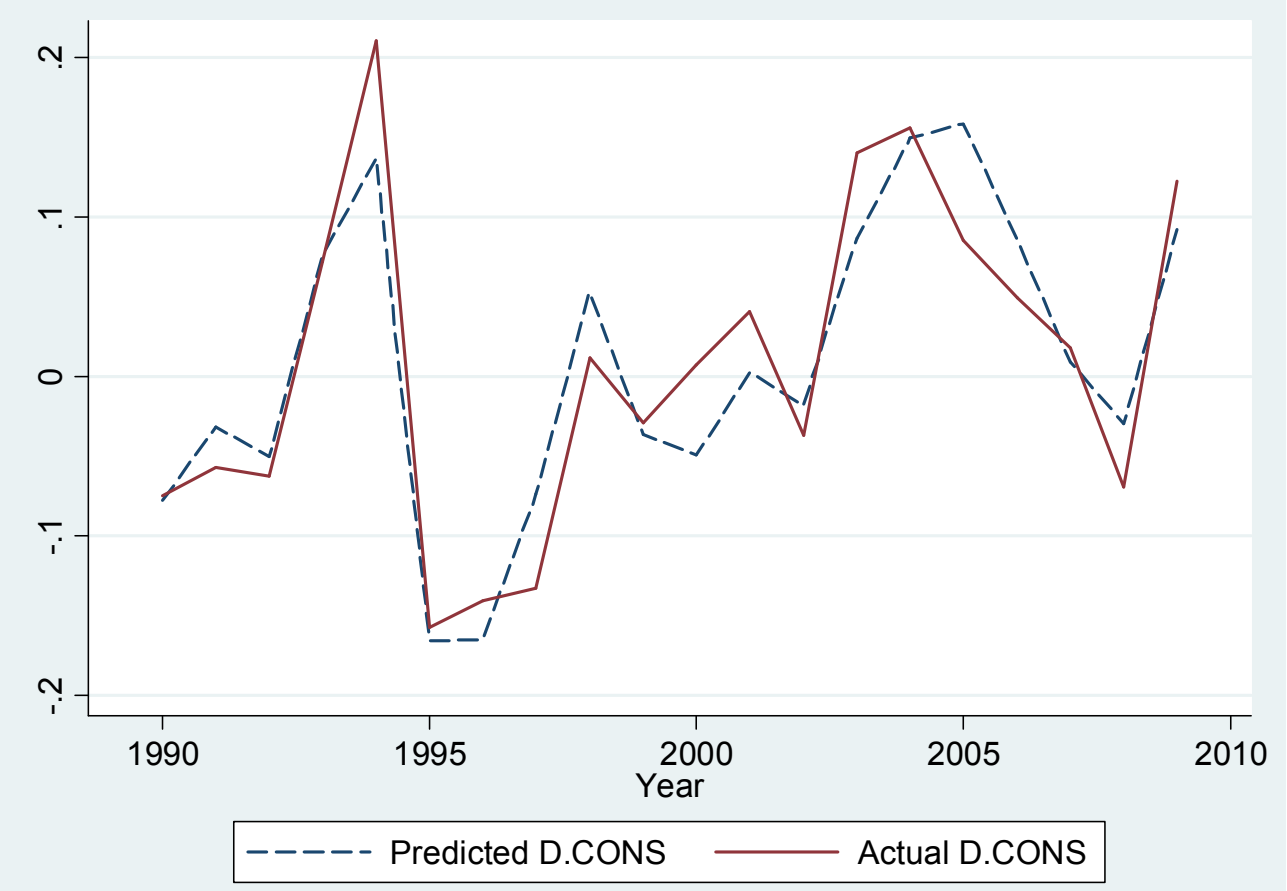

Note: Predicted construction activity growth is based on the specification presented in column (2), Table 3 . 


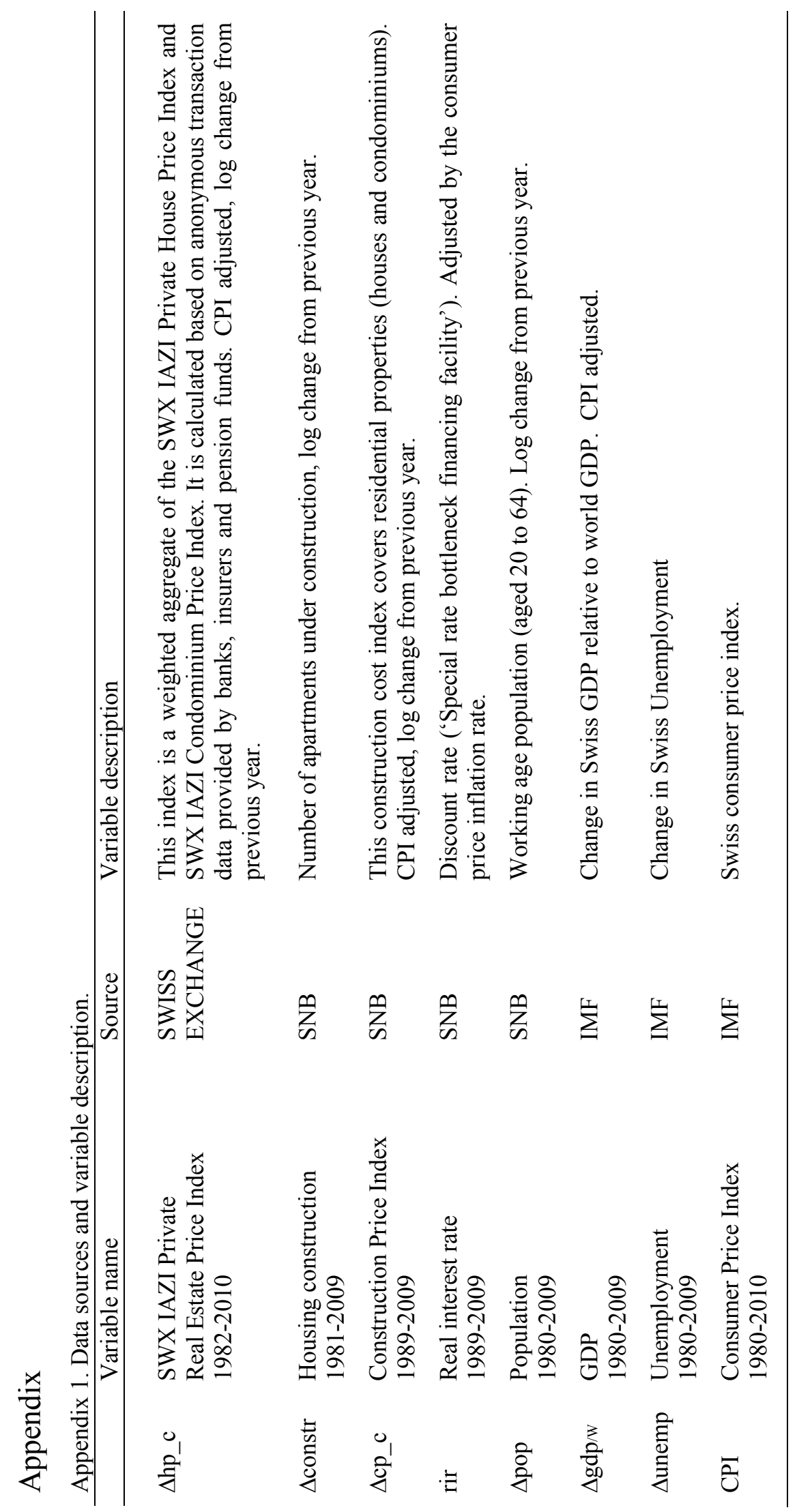




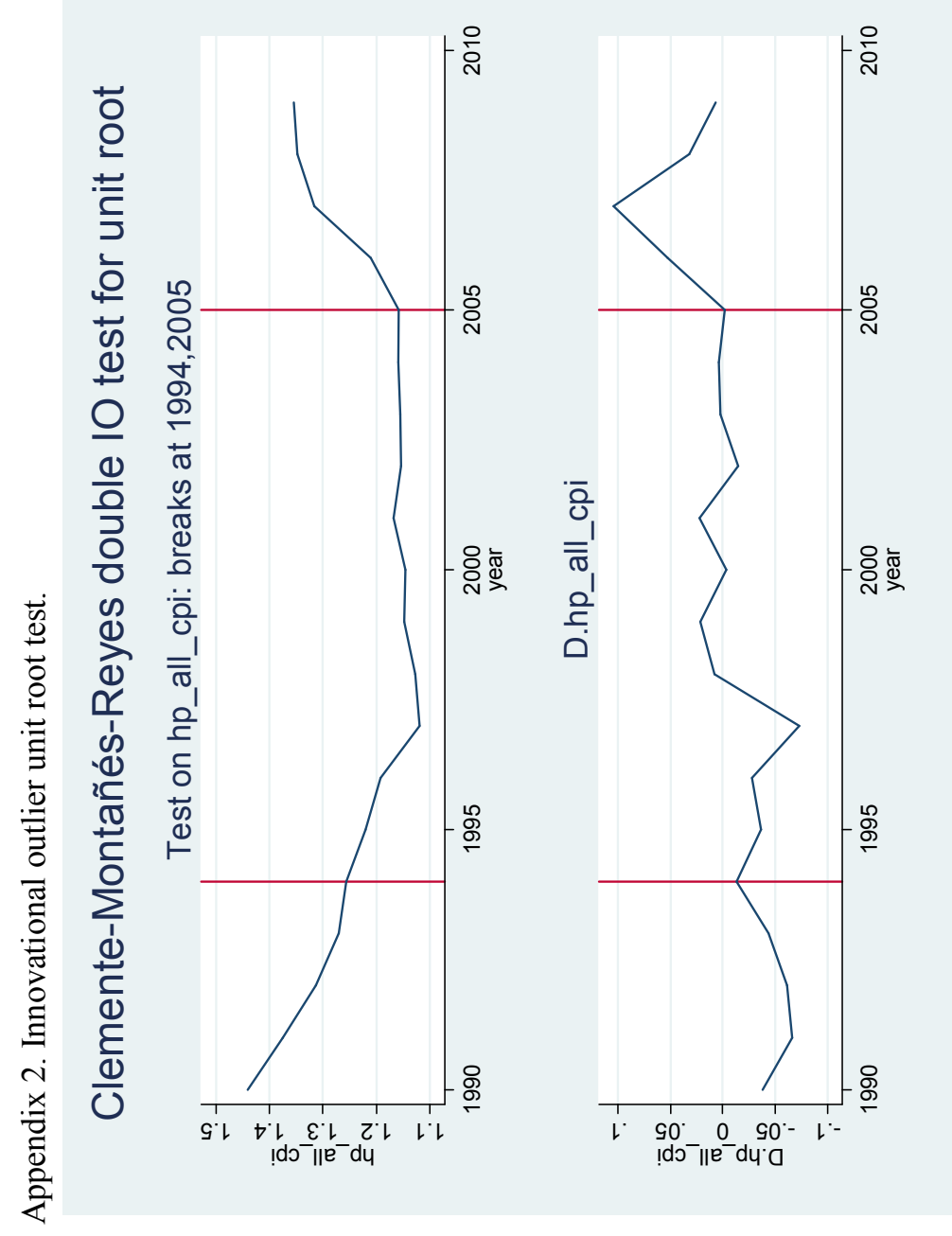

